\title{
The Figurative Language of Soviet Power and Georgian Literature
}

\begin{abstract}
The Soviet language of power can be seen as a set of basic, universal codes with the special connotation of referring to major principles of Soviet ideology or social/political goals prioritized by the Communist Party. This language was developed in political discourse by the Party's leading ideologists, and implemented within cultural/literary discourse. Ideological principles were often metaphorized and implemented in canonical texts: speeches by Party leaders, centrally developed poems and songs, epic novels. After this, the codes were used in all the national cultures/languages of the USSR. Through the bearers of the ideology - bigger and smaller Party leaders, poets, prose writers, and songwriters - the messages of power were communicated to the Soviet people. Based on Georgian material, this article discusses the spread of one of the main metaphors related to the multinational composition of the USSR - the metaphor of the "united brotherly family of the nations." The metaphor carried not only a political meaning but also a hidden agenda of suggesting to Sovietized nations both views and verbal formulations, and how to deal with the existing political reality and the dominance of the Russian centre. In this sense, it was an imperial metaphor, related to the national question and the centre-periphery model of the USSR.
\end{abstract}

Keywords: Georgian literature, metaphors/language of power, national question, Soviet ideology

The Soviet totalitarian power was one of the most consistent political regimes in creating and implementing its own language of power, which was developed as a specially designed system of communication, aimed to indoctrinate Soviet ideological principles all over the USSR. ${ }^{1}$ The Soviet language of power can be seen

1 It has been observed that most sociologists, political analysts, and philosophers are concerned with the ideological content of concepts; Adorno, Williams, Foucault, Lakoff, and Goatly are "but a few of those who remind us that words are not innocent and that political systems, reigning ideologies and competing world-conceptions seek to shape and delimit the content we attribute to words like 'citizen', 'individual', 'state' and 'nation'. [...] Poets have the capacity to shape our interior world, the intimate space within us, just as much as ideologies structure the frameworks within which we live and work. It would however be a mistake to consider that literature can be exiled to the private sphere. As readers and literary critics often affirm, writers transform our

2 Open Access. (C) 2021 Bela Tsipuria, published by De Gruyter. (c) BY-NC-ND This work is licensed under the Creative Commons Attribution-NonCommercial-NoDerivatives 4.0 International License. 
as a set of basic, universal codes with a special connotation, referring to major principles of Soviet ideology or social/political goals prioritized by the Communist Party. One part of the vocabulary of the language of power was formed on the basis of political concepts related to Western thought and Marxist philosophy, while another part was related to figures of speech. While developing the codes of political/ideological discourse, the representative resource of figurative language was widely used; the whole set of metaphors was developed specifically within the discourse of Stalin's totalitarianism, or the Soviet modification of Marxism. While the Marxist political concepts connected Soviet discourse with modernity, the metaphors and figures of speech revived the early patriarchal worldview and traditional system. We can see that, by means of frequency of usage and power over the masses, the metaphors gained much more strength within the Soviet totalitarian discourse than political concepts.

The figurative language of Soviet power was developed by the Party's leading ideologists within the political discourse, and implemented within the cultural/ literary discourse. Thus, Soviet-totalitarian metaphors can be seen as points of connection between Soviet politics and mass culture. Ideological principles which were first pointed out in political speeches were usually metaphorized and implemented in canonical texts of socialist realism - often a poem or a song, a novel or a film. After this, these political codes were used in other cultural texts, all over the Soviet state. Through the bearers of the ideology - bigger and smaller Party leaders, poets, prose writers, songwriters - the messages of power were communicated to the Soviet people. At the same time, the Soviet figurative language implied not only openly communicated political messages, but also hidden meanings intended to unify the mass consciousness of the Soviet people and subdue it to the regime.

A few main metaphors related to the multinational composition of the USSR were most commonly used in Soviet political/ideological discourse and literary texts. They carried not only a political meaning but also a hidden agenda of suggesting to Sovietized nations both views and verbal formulations, and how to deal with the existing political reality and the dominance of the Russian centre. In this sense, these were imperial metaphors, related to the national question and centre-periphery model of the USSR. The metaphors were approved as forms of officially mentioning the state, the leader of the state, reality. These were, indeed, the metaphors the Soviet people lived by, since they structured (and were actually designed to structure) the most basic understanding of people's experience

conception of the public sphere. Writers, whether 'engaged' or not, contribute to our conception of politics" (Underhill 2013, 3-4). 
and their perception of reality (see Lakoff 1980). The development of metaphors was not the job of poets, but of the political leadership. We can see how these metaphors were transmitted from political rhetoric to literature while the socialist realism style was implemented by Soviet power. ${ }^{2}$ As Evgeny Dobrenko has observed, texts of socialist realism do not have an author. The only creator of the socialist-realist text is a power. Totalitarian art is a convention, a deal between the bearers of power and language; through this art, there takes place a constant recreation and adaptation to the conventions of the new bearers of language through their inclusion in the discourse of socialist realism. If socialist realism is not created by an author, there are two sources left: power and language. Socialist-realist discourse is created only as a result of their interaction (Dobrenko 1993, 35-36).

We can trace the appearance and application of ideological metaphors as they are first heard from the highest Party leaders in the Soviet centre, quoted by the leaders of national republics, and finally used within cultural production. The Georgian material, less known to Western scholarship, will help to illustrate the process, which took place in similar ways in various national cultures of the USSR.

\section{Metaphor as a veiled colonizer}

Some Soviet ideological metaphors were most widely implemented in the 1930s, as part of the Stalin narrative, which suggested, or actually imposed on the Soviet people the new worldview, the pivot of which was the concept of happiness. The totalitarian discourse cultivated the state of "total" happiness in the Soviet people through various forms. "The pursuit of happiness" is now studied as an "important theme in the cultural history of Soviet society"; scholars "investigate the various social and artistic practices through which the idea of happiness in Soviet culture is manifested" (Balina and Dobrenko 2011, xv). The metaphor of the happy "brotherly family of the nations" can be considered as one of the forms with which the concept of Soviet happiness was suggested to the Soviet nations and how this concept had to work on a multinational level. The metaphor of "family" supported the myth of the brotherhood of Soviet nations. The same met-

2 On socialist realism in Georgian literature, see Gaprindashvili, Miresashvili, and Tsereteli (2010). 
aphor was used in producing the myth of the united all-Soviet people as a "Great Family" (see Clark 2000).

Scholars agree that the USSR was established as a modernized version of the Russian Empire. "The Bolshevik strategy was to assume leadership over what now appeared to be the inevitable process of decolonization and carry it out in a manner that would preserve the territorial integrity of the old Russian Empire" (Martin 2001, 2). The term "Soviet Empire" is widely used in Western scholarship. "Empire has become a common frame through which the Soviet state and its collapse are analyzed, with regard both to the relationship between the Soviet state and its multicultural population and to Soviet control over Eastern Europe" (Beissinger 2006, 294).

The "nationalities question" was essential to the Russian Empire, as it was to the USSR. However, the Bolshevik discourse, and later the Soviet discourse of the Stalin era, had to differentiate the nature of these two versions of the Russian-centred state. The USSR had to be represented from the bright side, in a most positive way, and all negative associations had to be detached from the new image of the state, which was formed almost with the same borders as the Russian Empire, and with the dominance of the same Russian nation. ${ }^{4}$ After two Russian revolutions and the dissolution of the Russian Empire in 1917, some nations, freed from the Empire, established their nation states, but within a few years, with the strengthening of the Bolshevik government, Russia annexed and gained back most of the territories of the former Empire, and in 1922 established a new multinational, Russian-dominated state, the Union of Soviet Socialist Republics. The Soviet-Russian centre had to face dissatisfaction among the Russian-dominated nations within the USSR, and it turned to both hard and soft power to ensure the political unity of the new state. In Georgia, by means of hard power, the national rebellions and protests were suppressed by the Bolsheviks in the 1920s, and nationally minded individuals were executed in the 1920s, and, later, in the Great Purge. Soft ideological power was fully activated by the early 1930s, when the official Soviet discourse was providing the views and formulations of the established Russian-centred reality. In order to manage the negative attitudes of various nations towards

3 Among the many books analysing the USSR in terms of the concept of empire from various disciplinary approaches, including, of course, history and political studies, quite a few present Soviet cultural or ethnographic reality within the frame of empire (cf. Hirsch 2005; Etkind 2011; Scott 2016).

4 The dominance of the Russian nation and the Russian centre is usually not denied when discussing the nature of the Soviet state, although an interesting new analysis of Russian imperialism suggests that it can be seen also as an "internal colonization" and that Russia as an empire colonized not only other nations but also itself (see Etkind 2011, 61-71). 
the centre, a new form of representation was developed: all negative feelings had to be transformed into memories and attributed to the past, to the Russian Empire, while new positive feelings had to be cultivated and attributed to the present, to the USSR. ${ }^{5}$

The binary opposition of the unhappy past and happy present was already widely used by Soviet ideology to describe the class struggle. The past, the Russian Empire and the tsarist regime, was represented from the Marxist viewpoint, in the light of class suppression and the exploitation of workers and peasants; the present, the Soviet state, of course, was shown as the time of equality and social justice. The same past-present dichotomy was deployed in support of the national question; in this case, however, Marxist concepts were not available, and the figurative resource of language was used, through which the main ideological messages were delivered.

As early as 1914, while criticizing the tsarist national policy, in order to escalate the spirit of civil conflict and achieve the "class solidarity of workers of various nationalities," ${ }^{6}$ Lenin accepted the formula "Russia - a prison of nations [or of peoples],"7 initially suggested by the Marquis de Custine. ${ }^{8}$ Stalinist-totalitarian discourse of the 1930s employed this metaphor often, although clarifying that it was about tsarist Russia and not, of course, about contemporary Russia. The metaphor served as an oppositional basis for one of the major metaphors of the Soviet state - a "brotherly family of the nations." While the preservation of the territorial integrity of the Russian Empire was, of course, one of the Bolshevik goals, the application of the metaphor of a "prison of the nations" in the Bolshevik revolutionary discourse was still related to the Marxist agenda, and could even be seen as anti-colonial. However, coupled with the concept of the brotherly family, the metaphor about the tsarist past gained colonial meaning and served to justify the

5 As research demonstrates, the patriotic Soviet rhetoric was very successful. In the 1930s, "the Soviet government had positioned itself as a repository of national sentiment and patriotism; its nation-building and national-strengthening projects could appeal even to citizens who complained about shortages and resented the privileges of the office-holding elite" (Fitzpatrick 2000, 225).

6 The quotations from Russian and Georgian, if not otherwise indicated in the references, have been translated into English by me.

7 In a draft speech, "K voprosu o natsionalnoi politike" (1914), Lenin criticizes the actions of Russian tsarism and its national policy, as a result of which "millions of philistines" were starting to realize the truth of the phrase that Russia is a "prison of nations" (Lenin 1969, 66).

8 Marquis de Custine's book Russia in 1839, published in Paris in 1843, was prohibited in the Russian Empire and circulated as illegal literature. In Soviet times, although even Lenin quoted from the book, only parts of it were translated and published. On the book, see Kennan (1972). 
new Soviet order: since the prison of the nations was transformed into the brotherly family of the nations, the logic of historical dialectics was celebrated and the idealistic goals of all suppressed classes and nations had been achieved. This was also how the concepts of "class struggle" for equality and "national struggle" for freedom were merged. Through this merger, the Soviet ideology completed the ideal picture of the state, showing it as a place of happiness and harmony between the classes and, also, between the nations. The "happiness of the nations" became the point emphasized from 1943 even in the anthem of the USSR. ${ }^{9}$ Thus, the set of binary metaphors implied the discourse of the colonizer while assuring the subjugated nations that peace, union, and support were attained within the social and national organization of the Soviet state. The substituted metaphors guided the changes in the emotional acceptance of reality: national struggle against the prison was already in the past, and the present should evoke feelings of peace and satisfaction. The Soviet nations would not have to worry about their sovereignty since they had already reached the highest level of historical development as part of the family, where each individual and each nation is equal.

In Marxism, the development of the "classless society" would also result in reconsidering and revising the concepts of nationalism, which before that were only a tool for the "ruling class," but the Soviet centre did not reject the role of nations and nationalities in the composition of the state. Instead, "it projected itself as a post-imperial form of power, a civic multinational state that aimed to transcend national oppression in the name of class solidarity" (Beissinger 2006, 295).

At first sight, one might assume that the Soviet system highly valued the presence of various nations in and contributions to the Union. Since the 1930s, the Soviet nations were actually given a variety of modes of self-representation, emphasizing the fact that they held their own languages, cultures, and national costumes. Within the USSR, they could even have their own borders as Soviet republics, flags, anthems, and constitutions, and their own Communist leaderships - reporting to the Soviet-Russian centre. Already in the 1930s, Stalin's totalitarian regime had developed instruments for controlling and even micromanaging the political, economic, cultural, and social life of Soviet republics. The Soviet hard power was there to ensure that, in reality, none of the Soviet nations

9 The USSR was represented as "the Motherland, home of the free,/ Bulwark of peoples in brotherhood strong” (lyrics by Mikhalkov and El-Registane, quoted here according to https://www. marxists.org/history/ussr/sounds/lyrics/anthem.htm [5 January 2019]). The first version of the anthem was approved by the Decree of the Politburo of the Central Committee of the Communist Party of the Soviet Union (B), 14 December 1943. 
would apply the right of self-determination, even though it was mentioned in the Soviet constitution, and could not even make any changes to the centre-established modes of everyday life. Thus, for the Soviet nations, beyond the clarity of forms of representation, there was a total ambiguity of forms of existence. It may be said that, at this point, for the Soviet political discourse, metaphorization was a way of escaping from the need to clarify reality and verbalize the true nature of the national organization of the Soviet state. It was clear that the Soviet nations were allowed to exist only within the Soviet borders, as a part of the Union, or of the brotherly family, while beyond the borders, for the rest of the world, the USSR was seen as a Russian state, with Russian politics and Russian culture and literature. This is also seen in the fact that most of the Western studies on Soviet literature/culture are focused on Russian material.

From various ideologized texts, we can see how figurative language gains power in the 1930s, and how the representative inclusion of the Soviet nations in the Soviet picture became one of the instruments of central power. From 17 August to 1 September 1934, one of most wide-ranging events of the 1930s, the First All-Soviet Congress of Soviet Writers, was held in Moscow. Fifty-four Soviet nations ${ }^{10}$ were represented by up to six hundred writers, and in total the Union at that stage had one thousand five hundred members. The Congress also gave the floor to the representatives of national literatures, of course, on the condition that they publicly expressed their readiness to become part of the centralized literary process.

Maksim Gorky’s $(1934,15)$ plenary report at the Congress is still Russian-centred, its antagonistic spirit is against bourgeois literature, and the vocabulary is more related to Marxist rather than Stalinist-totalitarian discourse. Gorky discusses the multinational/multicultural composition of the Soviet state while suggesting that Russian literature has to be inclusive towards the literatures of the Soviet republics, and these literatures should not be ignored just because the Russians are greater in number: "Armenians, Georgians, Tatars, Ukrainians and other tribes are also capable of producing great artists.” The established Soviet etiquette is followed in the report and at the Congress, and non-Russian republics are described as "brotherly."

It is notable that the metaphor of "family" was often used at the Congress, but at this stage it meant the family of Soviet writers rather than Soviet nations: it was suggested that the All-Soviet Writers' Union be seen as the artistic brotherly

10 Besides the sixteen, by that time, Soviet Socialist Republics, delegates represented autonomous republics and districts. The number of fifty-four nations is indicated in Congress documents (Pervii vsesoiuznii s'ezd 1934, 686). 
family that unites writers with different aesthetic backgrounds. ${ }^{11}$ The Congress, under Gorky's leadership, sent very clear messages to modernist writers all over the USSR in particular: non-Party writers would not exist any more in the Soviet state; they were to abandon their individualist ambitions and aesthetic ambiguity, and follow the Soviet writers' collective goals.

Two Georgian writers, former modernists, now forced to join the socialist-realist style and Soviet discourse, Mikheil Javakhishvili (1880-1937) and Nikolo Mitsishvili (1896-1937), applied to the figure of the "Soviet writers' family" in their speeches at the Congress: "Henceforth, Soviet writers of all nationalities of the Soviet Union will be rallied even more tightly into a united powerful family" (Javakhishvili 1934, 148). In reality, the unification of writers in one "family" was a process as painful and repressive as the unification of the Soviet nations. Up to two hundred and twenty delegates of the congress, among many others, were to be repressed in a few years in the Great Purge (see Kaverin 1997, 513-515); Javakhishvili and Mitsishvili were both executed in 1937 (see Elbakidze 2016, 201-220).

\section{Georgian literature and the "brotherly family"}

In the 1930s, the subduing of Georgia's public and literary discourse, ${ }^{12}$ and its representative inclusion in the totalitarian space, was a task of its own importance for the Russian centre, as in the 1920s it had become important to include Georgia in the new empire. As Georgia had spent the nineteenth century colonized by the Russian Empire, it was seen as a "Russian" land from the central, Russian perspective. Thus, together with other nation states established after the dissolution of the Empire - Ukraine, Armenia, and Azerbaijan, or, later, the Baltic states - it had to be gathered back into the new Russian state. The Sovietization of Georgia in 1921 was a military and political process performed with the personal involvement of ethnic Georgian Bolshevik revolutionaries in the first instance - Joseph Stalin and Sergo Orjonikidze. The Free Georgian Democratic Republic (1918-1921), a Western-style nation state established after the collapse of the Russian Empire,

11 "Long live the great family of Soviet writers!" - the celebratory motto was introduced at the opening of the Congress by the representative of Soviet workers, Comrade Izotov (Pervii vsesoiuznii s'ezd 1934, 19).

12 On the forms and instruments with which Soviet power tamed and subdued Georgian literature, see Bakradze (1990). 
was annexed and occupied by Russian Bolshevik troops in February $1921 .^{13}$ In August 1924, a national uprising was suppressed by the Bolsheviks, with thousands killed. In 1937-1938, the Soviet Great Purge was also performed most brutally in Georgia. The head of the Georgian Soviet Socialist Republic, the First Secretary of the Georgian Communist Party, Lavrenti Beria (1899-1953), coordinated not only the Purge in Georgia but also the process of ideologizing Georgian culture and aligning it with the centralized Soviet discourse. This was when he gained his reputation before becoming one of the most powerful figures around Stalin in Moscow in 1938, the Minister of Internal Affairs of the Soviet Union and the chief of the secret police. In Georgia, Beria is remembered as the brutal executor of the Great Purge. Donald Rayfield (2000, 261-270) calls his actions in Georgia in 1937-1938 “Beria's Holocaust.”14

In November 1937, Beria published a heavily ideologized political essay that also drew on the figurative language of Soviet power. By this time, thousands of Georgians had already been executed in the Purge, among them most notable Georgian writers, including the former modernists Mikheil Javakhishvili and Nikolo Mitsishvili. Paolo Iashvili (1894-1937) had already committed suicide as an act of protest in his office at the All-Georgian Writer's Union, and Titsian Tabidze (1895-1937) was to be executed soon. ${ }^{15}$

Beria's text illustrates how the metaphors of Soviet power were imposed by the ideological discourse on culture/literature, and by the centre on the periphery. The essay entitled "Khalkhta Ertiani Ojakhi" [The United Family of the Nations] (Beria 1937) was first published in the central newspaper Pravda on 7 November 1937, and republished in the local Georgian journal Mnatobi [Luminary], a monthly organ of the All-Georgian Soviet Writers' Union. ${ }^{16}$ It can be seen - and, we can assume, was indeed seen - as an instruction for how Georgian writers and

13 On the Georgian Democratic Republic, Soviet annexation, and the Sovietization of Georgia, see Urushadze (2005); Jones (2014); Rayfield (2000, 323-365).

14 As Rayfield writes: "Writers in the USSR were no longer individuals after 1932. They were collective state property, as much as the peasants' horses and pigs. They underwent a comparable slaughter and their fates make no sense unless seen as part of a process of prophylactic killing initiated by Stalin and, in Georgia, carried out with exceptional verve by Lavrenti Beria. [...] [In] 1927, when he won a dominant position in the Georgian Cheka, Beria built up dossiers on all the leading figures in literary groups, in the conservatory, in the university, targeting most for destruction, and a very few for survival in a cat-and-mouse game that was to amuse him for a decade" (2000, 261-262).

15 On Bolshevik repression of Georgian writers, see Elbakidze (2016).

16 Modelled on the central All-Soviet Writers' Union, the Georgian Union was itself a Soviet instrument for controlling literature in the GSSR. 
all citizens should speak about the Soviet reality, what to emphasize, and how to metaphorize it.

Beria's essay, and the whole issue of the journal Mnatobi, is dedicated to the twentieth anniversary of the October Socialist Revolution; it praises the "rise" of Soviet Georgia in the frame of the USSR. Turning to the highest source of legitimation, the essay opens with a quotation from Stalin: "Friendship among the nations of the USSR is a big and serious achievement. As long as the friendship is strong, our nations are free and unconquerable. Nobody is dangerous to us, neither internal nor external enemy, while this friendship is alive and long-lived"; the tone of the essay is, of course, celebratory, even triumphant, calling the time period since the Revolution "twenty years of the rise of the Soviet nations, unprecedented in the history of mankind," which witnessed "world-historical victories under the flag of the national policy of Stalin and Lenin." As his next point, Beria makes a comparison with the tsarist period, emphasizing that "tsarism was a dark 'prison of nations'; tsarist national policy was the policy of colonization, ruthless oppression, and licentious exploitation of enslaved nations." A further quotation from Stalin also concerns tsarist times, marked by the dichotomy of the centre and periphery, and insisting that "tsarism used to promote patriarchal-feudal oppression on the peripheries intentionally in order to keep the masses in slavery and ignorance" (Beria 1937, 5).

Of course, by stressing the difference between tsarist and Soviet Russia, Soviet ideologists were trying to reorganize the discourse of the Soviet nations, Georgia among them, and impose the only acceptable vision of their existence within the USSR. While the wording of Beria's essay is harsh and highly critical towards the "dark" past, it is ravishing in its praise of the bright present. Before moving to specifics about the Georgian people's achievements, he employs the familiar metaphor: "during the twenty years of Soviet rule, by steadily embodying the wise national policy of Stalin and Lenin, under the leadership of the Bolshevik Party and the great Stalin, the USSR eliminated the previous inequity in the economic and cultural development of nationalities. All Soviet nations are united in a big, inseparable Socialist family" (Beria 1937, 6).

The figures of "united/brotherly family" vs "prison of nations" are central to the Soviet political discourse on nationalities. In Beria's essay, they also represent the main principles for acceptance of the reality imposed by the Soviet-Russian centre on the Sovietized Georgian nation. The vision, and the metaphors enforced by the political leaders, had to be practised by poets. From the numerous poetic texts of the Stalin period, we can see how this dichotomy entered Georgian poetry and prose.

From the 1930s to the destalinization that began in 1956, Soviet literature is marred by numerous poetic and prose texts, as well as songs, paintings, posters, 
and films, praising Stalin. There is nothing normal in this tendency, and Western researchers have indeed demonstrated that "life in the Soviet Union in the 1930s was not 'normal,' that one could not 'make a normal life'” (Fitzpatrick 2000, 219). In the twentieth century, the time of modernization and industrialization, within the political tendency of the cult of personality, the whole genre of Stalin-dedicated texts, which resembles the medieval panegyric tradition, developed.

In Georgian literature, the process is, of course, similar to the central tendency. A special poetry collection was published in 1937 (Demetradze 1937). The preparation of the book seems to have been well coordinated by Beria. 1937 was the year of the celebrations marking the twentieth anniversary of the Bolshevik Revolution, but this was also the year of severe Soviet repression behind an intense public discourse applauding the Soviet system and its leader.

All major representatives of Georgian poetic circles of the time - more than twenty poets - are present in the book. We can see how all notable Georgian poets, who had been developing the modernist and avant-garde style in the 1910s and 1920s, were now forced to switch to socialist realism, producing poems admiring the "great leader." To be more precise, the concept of the leadership of Stalin was exactly expressed in Russian, as well as in Georgian, not by the modern words for "leader," but by the archaic words for “chieftain” (Вождь and ठэмзœо), reviving the archetypal image of a powerful spearhead and restoring the patriarchal vision. In many texts, Stalin was represented through mythological symbols, or his glory was described through the flowering of nature; in the background, usually, the images show the prosperity of Soviet Georgia.

Giorgi Leonidze (1899-1966) a former modernist poet, produced a whole cycle of poems, as well as a trilogy of epic poems on Stalin. One of the poems expresses his "brotherly embrace" of the Uzbek, Belarusian, and Armenian nations, indeed of all "revived nations" (Leonidze 1939, 13). We can see how the image of the brotherhood of nations was entering Georgian poetry by the end of the 1930s; it was to remain one of the popular forms of praising the Soviet system until the very end of the Soviet regime.

The poetic texts published in the collection of 1937, with the addition of a few poems and some stories and short memoirs on Stalin, were republished in a new collection dedicated to the sixtieth anniversary of Stalin's birth in 1939. However, the repressed poets Paolo Iashvili, Titsian Tabidze, and Nikolo Mitsishvili were now missing from the anthology. Their books would be banned until destalinization commenced in 1956, as would the books by the executed Mikheil Javakhishvili, who in one of his novels, Qalis Tvirti [The Woman's Burden] (1936), dared to reveal the true evil nature of a young Bolshevik leader modelled on Stalin (see Tsikarishvili 2002, 339-356). From this novel, as well as some other texts by former modernist writers, including Leo Kiacheli's (1884-1963) stories, and Titsian 
Tabidze's and Galaktion Tabidze's (1892-1959) poems, we can see that, even in the 1930s, Georgian literature was developing an allegorical language of resistance to totalitarianism and Soviet power, which would grow into a consistent tendency in the Georgian literature of the second half of the twentieth century.

\section{Works cited}

Bakradze, Akaki. Mtserlobis Motviniereba [The Taming of Literature]. Tbilisi: Sarangi, 1990.

Balina, Marina, and Evgeny Dobrenko. "Introduction." Petrified Utopia: Happiness Soviet Style. Ed. Balina and Dobrenko. London: Anthem Press, 2011. xv-xxiv.

Beissinger, Mark R. “Soviet Empire as “Family Resemblance.” Slavic Review 65.2 (2006): 294-303.

Beria, Lavrenti. “Khalkhta Ertiani Ojakhi” [The United Family of the Nations]. Mnatobi [Luminary] 10 (1937): 5-13.

Clark, Katarina. "Stalinskii mif o "Velikoi Semie”" [The Stalinist Myth of the "Great Family"]. Sotsrealisticheskii Kanon [The Socialist-Realist Canon]. Ed. Hans Günther and Evgeny Dobrenko. St Petersburg: Akademicheskii proekt, 2000. 785-796.

Clark, Katarina, and Evgeny Dobrenko. Soviet Culture and Power: A History in Documents, 1917-1953. Trans. Marian Schwartz. New Haven and London: Yale University Press, 2007.

Demetradze, David, ed. Qartuli Leqsebi da Simgerebi Stalinze [Georgian Poems and Songs on Stalin]. Tbilisi: Zaria Vostoka, 1937.

Dobrenko, Evgeny. Metafora vlasti: Literatura stalinskoi epokhi v istoricheskom osveshchenii [The Metaphor of Power: Literature of the Stalin Era in a Historical Light]. Munich: Sagner, 1993.

Elbakidze, Maka, and Irma Ratiani, eds. Bolshevizmi da Qartuli Literatura, 1921-1941 [Bolshevism and Georgian Literature, 1921-1941]. Tbilisi: Shota Rustaveli Institute of Georgian Literature, 2016.

Etkind, Alexander. Internal Colonization: Russia's Imperial Experience. Cambridge: Polity Press, 2011.

Fitzpatrick, Sheila. Everyday Stalinism: Ordinary Life in Extraordinary Times: Soviet Russia in the 1930s. Oxford: Oxford University Press, 2000.

Gaprindashvili, Nana, Mariam Miresashvili, and Nino Tsereteli. Sotsialisturi Realizmis Teoriuli Istoria: Qartuli Literaturis Magalitze [Theoretical History of Socialist Realism: The Case of Georgian Literature]. 2 vols. Tbilisi: Nekeri, 2010.

Gorky, Maxim. “Doklad A. M. Gorkogo o sovetskoi literature” [A. M. Gorky's Report on Soviet Literature]. Pervii vsesoiuznii s'ezd sovetskikh pisatelei: 1934: Stenograficheskii otchet [First All-Union Congress of Soviet Writers: 1934: Stenographic Report]. Moscow: Khudozhestvennaia literatura, 1934. 5-18.

Hirsch, Francine. Empire of Nations: Ethnographic Knowledge and the Making of the Soviet Union (Culture and Society after Socialism). Ithaca and London: Cornell University Press, 2005.

Javakhishvili, Mikeil. “Doklad” [Report]. Pervii vsesoiuznii s'ezd sovetskikh pisatelei: 1934: Stenograficheskii otchet [First All-Union Congress of Soviet Writers: 1934: Stenographic Report]. Moscow: Khudozhestvennaia literatura, 1934. 74-102. 
Jones, Stephen J. The Making of Modern Georgia, 1918-2012: The First Georgian Republic and Its Successors. London: Routledge 2014.

Kaverin, Veniamin. Memuari [Memoirs]. Moscow: Agraf, 1997.

Kennan, George F. The Marquis de Custine and His Russia in 1839. London: Hutchinson, 1972.

Lakoff, George, and Mark Johnson. Metaphors We Live By. Chicago: University of Chicago Press, 1980.

Lenin, Vladimir. "K voprosu o natsionalnoi politike" [On the Issue of National Policy]. Polnoe sobranie sochinenii [Complete Works]. By Lenin. Vol. 25. Moscow: Izdatelstvo politicheskoi literaturi, 1969. 65-72.

Leonidze, Giorgi. Stalini: Leqsebis Krebuli [Stalin: Collection of Poems]. Tbilisi: Sablitgami, 1939.

Martin, Terry. The Affirmative Action Empire: Nations and Nationalism in the Soviet Union, 1923-1939. Ithaca: Cornell University Press, 2001.

Pervii vsesoiuznii s'ezd sovetskikh pisatelei: 1934: Stenograficheskii otchet [First All-Union Congress of Soviet Writers: 1934: Stenographic Report]. Moscow: Khudozhestvennaia literatura, 1934.

Rayfield, Donald. The Literature of Georgia: A History. 2nd ed. Richmond: Curzon Press, 2000.

Scott, Erik R. Familiar Strangers: The Georgian Diaspora and the Evolution of Soviet Empire. New York: Oxford University Press, 2016.

Tsikarishvili, Lela. “Mikheil Javakhishvilis ‘Qalis Tvirtis' Sakhismetkvelebisatvis” [On the Tropology of Mikheil Javakhishvili’s A Woman's Burden]. Literaturuli Dziebani [Literary Research] 23 (2002): 339-356.

Underhill, James. Creating Worldviews: Metaphor, Ideology and Language. Edinburgh: Edinburgh University Press, 2013.

Urushadze, Levan. Bolshevizmi-Menshvizmi da Sakartvelos Demokratiuli Respublika (1918-1921) [Bolshevism-Menshevism and the Democratic Republic of Georgia (1918-1921)]. Tbilisi: Ena da Kultura, 2005.

Bela Tsipuria is professor of Comparative Literature and Georgian Literature, and director of the Institute of Comparative Literature at Ilia State University, Tbilisi, Georgia. She specializes in twentieth-century Georgian literature and comparative literature, focusing on intercultural contacts; modernism, avantgarde, and postmodernism in Georgia; as well as Soviet ideological influences and post-colonialism. 
